\title{
Liability of the Institutional Lender for Structural Defects in New Housing
}

During the past two decades new real estate merchandising techniques have altered the structure of the residential construction industry. In 1950 the average home builder constructed four to six houses per year; ${ }^{1}$ today housing developments of several hundred individual units are common. ${ }^{2}$ Tract developers combine market functions: They not only build homes, but also serve as the salesmen of the finished products.

The courts have reacted quickly to the changing residential construction industry by finding "products liability" remedies for home purchasers who have suffered personal injuries or property damage as a result of construction defects. ${ }^{3}$ The earliest decisions relied on the doctrine of fraud or intentional misrepresentation to defeat the defense of caveat emptor. ${ }^{4}$ In later cases any misrepresentation of fitness by the builder, whether intentional or negligent, would enable a purchaser to recover damages or rescind a completed sale. 5 The absence of "privity" has been held not to preclude recovery for personal injury or property damage, with subsequent purchasers and third persons being allowed causes of action sounding in negligence. ${ }^{6}$ In such cases the fact that the building was finished at the time of purchase by the plaintiff is irrelevant. ${ }^{7}$ Where the action is brought to recover the cost of repairs on a theory of breach of an implied warranty of fitness, however, most courts have allowed the suit only where the structure was unfinished at the

1 Abrams, The Residential Construction Industry, in W. ADAMS, THE STRUCTuRE of AMERICAN INDUSTRX 108, 112 (Ist ed. 1950).

2 The profile of the homebuilder and the size of his projects changed rapidly during the 1950's. See Rogg, The Changing Home Building Industry, in UnItEd States Savings \& LoAN League, Savings \& Loan ANNALS 1960 at 167, 175.

3 See generally, Bearman, Caveat Emptor in Sale of Realty-Recent Assaults upon the Rule, 14 VAND. L. REv. 541 (1961); Dunham, Vendor's Obligation as to Fitness of Land for a Particular Purpose, 37 MrN. L. REv. 108 (1953).

4 See Finefrock v. Carney, 263 P.2d 744 (Okla. 1953).

5 Bearman, supra note 3 , at 562-63.

6 Cf. McPherson v. Buick Motor Co., 217 N.Y. 382, 111 N.E. 1050 (1916).

7 Pastorelli v. Associated Engineers, Inc., 176 F. Supp. I59 (D.R.I. 1959) (personal injury); Dow v. Holly Mfg. Co., 49 Cal. 2d 720, 321 P.2d 736 (1958) (wrongful death); Schipper v. Levitt \& Sons, Inc., 44 N.J. 70, 207 A.2d 314 (1965) (personal injury); Fisher v. Simon, 15 Wis. 2d 207, 112 N.W.2d 705 (1961) (property damage). 
time of contract, ${ }^{8}$ but a few have sustained the cause of action where the house was already completed at the time of sale. ${ }^{9}$

Thus, the courts have increased the number of plaintiffs who can recover both by widening the grounds for relief and by enlarging the class of persons entitled to sue. Recently a few courts, following the lead of the New Jersey Supreme Court in Schipper v. Levitt b Sons, Inc. ${ }^{10}$ have held builders strictly liable in tort for injuries resulting from the faulty construction of homes in housing developments. ${ }^{11}$

Yet those suffering personal injuries and property damage from faulty housing construction have often found their products liability remedies inadequate. The culpable land development companies are frequently either insolvent ${ }^{12}$ or defunct ${ }^{13}$ when building defects are first discovered, leaving aggrieved home purchasers without redress for damages caused by faulty construction. Unlike other "manufacturing" industries, the residential construction field is characterized by thousands $^{14}$ of small, undercapitalized ${ }^{15}$ firms which can easily enter and depart from the industry in accordance with fluctuations in housing

8 See, e.g., Weck v. A.M. Sunrise Constr. Co., 36 Ill. App. 2d 383, 184 N.E.2d 728 (1962); Vanderschrier v. Aaron, 103 Ohio App. 340, 140 N.E.2d 819 (1957); Jones v. Gatewood, 381 P.2d 158 (Okla. 1963); Hoye v. Century Builders, Inc., 52 Wash. 2d 830, 329 P.2d 474 (1958).

9 This rule applies at least in Colorado, Louisiana, and South Dakota. See Carpenter v. Donahoe, 388 P.2d 399 (Colo. 1964); Toraso v. Custom Built Homes, Inc., 144 So. 2d 459 (La. App. 1962); Waggoner v. Midwestern Dev't, Inc., 154 N.W.2d 803 (S.D. 1967).

1044 N.J. 70, 207 A.2d 314 (1965).

11 See, e.g., State Stove Mfg. Co. v. Hodges, 189 So. $2 \mathrm{~d} 113$ (Miss. 1966). For a judicial comment on the extension of strict liability to residential construction, see Macomber $v$. Cox, 435 P.2d 462, at 465 (Ore. 1967). The Schipper decision, involving a mass developer of houses, was based upon alternative theories of negligence and strict liability in tort. The New Jersey Supreme Court has recently expanded its Schipper doctrine by holding that all builders and contractors are to be held liable for damages caused by negligent construction in housing. Totten v. Gruzen, - N.J. -, - A.2d - (July 11, 1968).

12 See Connor v. Conejo Valley Dev't Co., 61 Cal. Rptr. 333 (Dist. Ct. App. 1967).

There are apparently no available statistics on the solvency of land developers, but there is much authority emphasizing the builder's plight of undercapitalization. See Brehm, The Residential Construction Industry, in W. Adams, The Sxructure of AMERICAN INDUSTRY 113, 118 (3d ed. 1961) [hereinafter cited as Brehm]; Lefcoe \& Dobson, Savings Associations as Land Developers, 75 YALE L.J. 1271, 1276 (1966) [hereinafter cited as Lefcoe \& Dobson].

13 Final Report from the Subcomm. on Houstng of the House Comm. on Banking \& Currency, 82d Cong., 2d Sess. 11 (1952). Often a builder will incorporate, build carelessly, and then dissolve the corporation in order to avoid liability. Id.

14 The trend, however, is toward fewer and larger firms in the industry. In 1949 there were 109,000 home builders in America. By 1964 the number of home builders had declined to approximately 50,000. United States Savings \& Loan League, Savings \& Loan ANNALS 1964 at 113.

15 See authorities cited note 12 supra. Lefcoe and Dobson report that even many large builders share the small builders' plight of undercapitalization. Lefcoe \& Dobson at 1276. 
demand. Frequently, the builders of housing developments obtain almost total financing from lending institutions, usually savings and loan associations. ${ }^{16}$

In future litigation, aggrieved home purchasers are likely to look beyond irresponsible builder-vendors to the institutional lenders standing behind them to recover for damages caused by structural defects in housing. Already a California District Court of Appeal, in Connor v. Conejo Valley Development Co., ${ }^{17}$ has held that:

Those who furnish almost total financing for tract construction ... thereby undertake a duty to that segment of the public which represents the potential market for such dwellings, at least to the extent of protecting these persons from gross structural hazards. ${ }^{18}$

Should other courts, following the lead of the District Court of Appeal in Connor, impose "lender liability," it will become necessary to define the nature and scope of such liability.

This comment will discuss considerations relevant to both the issue of whether a duty should be imposed upon lending institutions to protect home purchasers from structural defects and the problems courts will confront in defining the scope of such a duty should it be imposed. In order to discuss these issues, however, it is necessary first to examine the structure and financial arrangements of the residential construction industry.

\section{The Residential Gonstruction Industry}

\section{A. Structure}

The residential construction industry consists of two basic groups. Roughly half of the home builders in America construct twenty or fewer houses per year. ${ }^{19}$ This portion of the industry usually contracts to build homes for owners of land, rather than combining the functions of builder and vendor. The rights and obligations of the parties are

16 Interview with Lester J. Ballerine, Assistant Vice President, First Federal Savings and Loan Association of Chicago, June 4, 1968 [hereinafter cited as First Federal Interview].

1761 Cal. Rptr. 333 (Dist. Ct. App. 1967). The Connor case was argued before the California Supreme Court on April 2, 1968 after a petition for hearing was granted by that court on October 5, 1967.

1861 Cal. Rptr. 333, 344 (Dist. Ct. App. 1967).

19 See Brehm at 124; Rogg, supra note 2, at 175. According to the Bureau of the Census, $60 \%$ of single-family nonfarm houses built in 1964 were constructed by speculative developers and $40 \%$ were contracted for by the owner and constructed by one general contractor. United States Savings \& LoAN League, 1965 Savings \& LOAN Fact Book 38-41 [hereinafter cited as 1965 FACr Book]. 
normally set out in a construction contract, and the owner may visit the construction site in order to inspect the progress of work. "Products liability" remedies have not been generally applied to this type of home construction. ${ }^{20}$

The other segment of the industry is frequently termed "speculative" building because the builder normally does not contract with purchasers before construction, but instead develops large subdivisions and relies on mass-production merchandising to sell his homes. ${ }^{21}$ This portion of the industry produces over 90 per cent of the nearly one million single-family dwellings built each year. ${ }^{22}$ While a few extremely large speculative builders have emerged in recent years, ${ }^{23}$ these firms do not dominate the market. ${ }^{24}$ Tract developments often require multimillion dollar investments, ${ }^{25}$ but the average home builder's assets are approximately $\$ 35,000-\$ 40,000 .^{26}$ When demand for housing is great, the undercapitalized developer often purchases large tracts with funds acquired at high rates of interest, ${ }^{27}$ is compelled to "cut corners" in construction, ${ }^{28}$ and sells the completed houses as quickly as possible.

20 One distinction the Schipper court made to avoid overruling earlier decisions was that products liability remedies apply in the residential construction field only to "mass builder vendors." Schipper v. Levitt \& Sons, Inc., 44 N.J. 70, at 86-87, 207 A.2d 314, at 323 (1965). Apparently, others have suggested this distinction. See Note, 1963 WIs. L. REv. 343,351 .

21 Brehm at 124-25.

22 In a study of 7,000 home builders made by the National Association of Home Builders in 1960, it was found that: "Although the median builder put up 20 units [in 1959], the arithmetic mean was 60 units per builder; about two-thirds of all the units were built by $20 \%$ of the builders. Half of the group accounted for $92 \%$ of the total; the other half accounted for only 8\%": Rogg, supra note 2, at 175.

In the period between 1959 and 1965 there were an average of 996,460 single-family non-farm housing starts per year. 1967 Economic REPORT of THE President 256. During the period between 1951 and 1958 the average number of single family housing starts was 973,000 per year. Brehm at 116. On the other hand, during the period between 1929 and 1944, there were only 234,300 single-family housing starts per year. 1967 Economic Report of the President 256.

23 Lefcoe \& Dobson at $1277-78$ n.19.

24 Id. Accord, Brehm at 120.

25 The average cost of constructing a single-family dwelling at the end of 1964 was $\$ 15,575.1965$ FACT Boor at 44. Loan associations sometimes finance housing developments of up to 500 homes. Interview with Earl Murray, Loan Officer of Bell Savings and Loan Association, in Chicago, June 4, 1968 [hereinafter cited as Bell Interview]. See Connor v. Conejo Valley Dev't Co., 61 Cal. Rptr. 333 (Dist. Ct. App. 1967).

26 Brehm at 125 . There appear to be no available data on the relationship between land developers' assets and the size of their projects. But see Connor v. Conejo Valley Dev't Co., 61 Cal. Rptr. 333, 341 (Dist. Ct. App. 1967), for a situation in which an extensive project was undertaken with the builder's assets amounting to less than $\$ 50,000$.

27 Lefcoe and Dobson found that during the fourth quarter of 1965 state-chartered loan associations in California reported yields on construction loans from $13.5 \%$ to $16.8 \%$. Lefcoe \& Dobson at 1276, n.16.

28 There are many indications of developers sacrificing workmanship in order to realize 
Home purchasers have complained bitterly of inferior construction by tract developers, ${ }^{29}$ yet control over the industry by public agencies has been largely ineffectual. Critics of building code enforcement practices have asserted that code standards are frequently outdated and costly to enforce, and that inspectors, closely tied with the building industry, are sometimes corrupt. ${ }^{30}$ Licensing of builders, where required, is said to be controlled by the industry itself, resulting in the preservation of existing licensees, restriction of entry, and minimization of competition. ${ }^{31}$ Extended liability insurance is available to speculative developers, ${ }^{32}$ but indications are that few developers insure against losses caused by faulty construction. ${ }^{33}$ Products liability remedies are of little value against an uninsured, thinly capitalized or insolvent developer.

While it appears that public control over construction quality is inadequate and private remedies against land developers are sometimes ineffective, the lending institutions which finance residential construction projects have been able to exercise some control over the quality of workmanship in land development. An examination of construction lending practices should clarify how this control is exercised.

\section{B. Financing the Housing Development}

Although all institutional lenders may finance speculative construction, in practice, savings and loan associations provide the preponderant share of financing for undercapitalized land developers. ${ }^{34} \mathrm{~A}$ reason for this concentration of savings and loan funds in residential

a speedy return on investment. See Committee Report, supra note 13, at 11; Connor v. Conejo Valley Dev't Co., 61 Cal. Rptr. 333 (Dist. Ct. App. 1967); G. Lefcoe, LANo DEvelopMent LAW 388 (1966); Prentice, Financing Obsolete Mortgage Risks, in UnIred States Savings \& Loan League, Savings \& Loan Annals 1963 at 36, 39; Lefcoe \& Dobson at 1293.

29 See Commitee Report, supra note 13; 82d Cong., 2d Sess., House Comm. on Banking \& Currency, Subcomm. on Housing, Hearings on H.R. 436 (1952).

30 See G. Lefcoe, Land Development Law 387-89, 397 (1966).

31 See Edwards, Legal Requirements that Building Contractors Be Licensed, 12 LAw \& ConteMr. Prob. 76, 81-83 (1947).

32 7A Appleman, Insurance Law and Practice $\$ 45.08$ (1962).

33 See Sarnicandro v. Lake Developers, Inc., 55 N.J. Super. 475, 484, 151 A.2d 48, 53 (1959); Connor v. Conejo Valley Dev't Co., 61 Cal. Rptr. 333 (Dist. Ct. App. 1967) (by implication).

34 Loan associations financed approximately 442,000 new dwellings in 1964, or $29 \%$ of all private housing starts. 1965 FACT BooK at 65 . Between 1960 and 1964, savings and loan funds consistently financed approximately $30 \%$ of all private residential construction. Id. at 67 . These statistics obscure the fact that loan associations provide almost all the loan funds for undercapitalized, speculative land developers. First Federal Interview. $A c$ cord, Lefcoe \& Dobson at 1284-87. 
construction was stated in a recent discussion of savings associations' involvement in land development:

The small developer's lifeline is the savings and loan association. This is where he obtains funds for real estate projects that are too small and too risky to raise even an investigation from most banks and life insurance companies. Savings associations survive by paying a higher rate of interest than banks, and they need the extra margin that small builders are willing to pay to finance their speculative ventures. ${ }^{35}$

Another reason why savings and loan associations provide the major source of construction loan funds is to obtain a favorable position in the market for mortgages on the newly constructed homes. The savings association is generally more interested in obtaining a mortgage of long duration than a short-term construction loan, since its business return is derived from interest income. ${ }^{36}$ In order to obtain "end loans," or mortgages, savings associations often insert a penalty clause in construction loan contracts providing that the builder-vendor will forfeit a stated amount, usually $\$ 100$, for every purchaser who does not obtain a mortgage with the construction lender. ${ }^{37}$ Arguably, the builder who solicits "end loans" for his construction lender is in fact the lender's agent in the home financing transaction. ${ }^{38}$

Savings and loan representatives have frequently asserted that loan

35 Lefcoe \& Dobson at 1271. (footnotes omitted) In 1964 the estimated average annual yield of a savings account in a savings and loan association was $4.19 \%$, while the average return on a time or savings deposit in a commercial bank was $3.47 \% .1965$ FACT Book at 16. These figures are representative of recent years. Id. In 1964 savings and loan associa: tions took legal or distress actions against $0.53 \%$ of all their borrowers, as compared with $0.46 \%$ for all lenders. $I d$. at 77 .

36 This statement must be qualified to the extent that, in a period of rising interest rates, institutional lenders will prefer to lend for short terms rather than tie up their funds for extended periods at a fixed rate. But see note 37 infra.

37 The penalty system appears to be a standard construction loan practice among savings associations in Chicago. According to Lester J. Ballerine of First Federal Savings and Loan Association of Chicago (which employs the penalty system), the savings association is usually not interested in making construction loans at all unless they show promise of leading to more attractive mortgage loans. Often savings associations will actually solicit developers in order to increase mortgage business. First Federal Interview, Some loan associations do not impose a penalty on builders for all purchasers who finance elsewhere but, like Bell Savings and Loan Association of Chicago, only penalize builders if less than an agreed-upon percentage of purchasers (usually around 70\%) obtain mortgage funds from the construction lender. Bell Interview. Other forms of penalty provisions may also be employed. For example, the builder-vendor may obtain a mortgage on the property from the construction lender. Sale to the purchaser will involve an assumption of the mortgage; if the purchasex wishes to obtain financing elsewhere, it will be at the price of a prepayment penalty equal to several months' interest.

38 See notes 112-121 infra and accompanying text. 
associations are far more concerned with the quality of workmanship than are the builders themselves. ${ }^{39}$ The builder's relationship with the purchaser, and with the home, terminates upon the sale; the loan association continues to deal with the purchaser for many years as his mortgagee. If faulty construction makes a house obsolete or uninhabitable during the term of the mortgage loan, the home owner may default on his mortgage payments. State anti-deficiency judgment statutes provide extensive protection for mortgagors; ${ }^{40}$ faulty construction, therefore, may ultimately cost the loan association a large part of its investment. For this reason, as well as to protect their security for construction loans, loan departments of savings and loan associations carefully police the quality of construction work at each stage of the building process. This concern for quality workmanship has led one authority to assert that throughout the development process the lender really represents the purchaser's interests. ${ }^{41}$

To acquire the expertise necessary to police housing developments, savings associations have extensively educated loan officers and their staffs on intricate details of the construction process. The United States Savings and Loan League is completing a comprehensive Construction Lending Guide which provides an exhaustive analysis of procedures to be followed by loan association officials and construction standards to be met by builders at every stage of construction. ${ }^{42}$ The Guide is much relied upon by loan officers and serves as a text book for American Savings and Loan Institute courses. Loan association expertise in construction has grown rapidly in recent years, and savings and loan

39 See, e.g., Prentice, note 28 supra, at 39, 42; Panel Discussion on Residential Construction Standards, reported in UnIted States Savings \& Loan League, Savings \& LoAN ANNALS 1961 at 151 (statement of C.W. Ford).

40 One form of statute limits the amount of a deficiency judgment to the difference between the obligation and the fair market price of the house ("as the court may determine to be just and equitable") or the foreclosure price, whichever is higher. See N.Y. Rear. Pror. Actions LAw \$ 1371 (1963). Other states have passed similar laws. See, e.g., N.D. CENT. CODE § 82-19-06 (1959). The California statute bars any deficiency judgment under a mortgage given to a lender to secure a loan which was used to purchase a residence for less than four families. CAL. Crv. Proc. CODE \$ 580(b) (Supp. 1967).

41 Prentice, note 28 supra, at 42 (quoting economist Miles Colean).

42 The League estimates that the final edition of the Guide will be available by 1969 . Most sections have been completed, however, and have been in use in local savings associa. tions since 1964. Various volumes of the Guide pertain to loan procedures and appraising proposed developments. The following sections are included in the volume on construction materials and workmanship, the largest portion of the Guide: Construction Standards, Structural Principles, Soil Mechanics, Moisture Control, Heat Control, Sound Control, Fire Resistance, Land Survey and Description, Codes, Drawings and Specifications, Inspections, Cost Estimating, twenty-five sections on materials and products, twenty-six sections on methods and systems, thirty-one sections on applications and finishes, and five sections on mechanical services. 
appraisers and inspectors are well qualified to evaluate the quality and workmanship of building projects. ${ }^{43}$ Some of the larger associations also have architects on their payrolls. ${ }^{44}$

Savings associations utilize their expertise and financial bargaining power to "control" builders at three different stages in the construction loan process: application for the loan, appraisal of plans and specifications, and inspection of the building site.

1. Application for the Loan. Before lending to a particular buildervendor, a savings and loan association will make an extensive check of the builder's credit record and experience. In many metropolitan areas suppliers of building materials and lending institutions pool their records on the financial history and work performance of land developers for the purpose of "informing one another of bad experiences" in dealing with speculative builder-vendors. ${ }^{45}$ In other areas loan associations rely heavily on credit agency reports which list prior construction experience, previous lenders, mechanic's liens, and persons for whom the developer has built in the past. ${ }^{46}$ Lenders often make informal telephone calls to previous lenders and owners of buildings constructed by the builder to inquire whether the builder's work has been satisfactory. The primary purpose of this initial screening is to determine the developer's credit rating, but lenders also take into consideration the quality of the builder's previous work.

2. Appraisal of Plans and Specifications. Appraisal of plans and

43 Loan officers interviewed at Talman Federal Savings and Loan Association of Chicago, Bell Savings and Loan Association of Chicago, and First Federal Savings and Loan Association of Chicago agreed that staff appraisers and inspectors have had years of experience with the construction industry, are thoroughly trained in their functions, and normally specialize in one phase or another of the loan policing process. Moreover, the United States Savings and Loan League's Legal Bulletin, while criticizing the California District Court of Appeal's decision in Connor, conceded that the large institutional lender possesses the necessary "expert technical knowledge" to assume the risks of improper construction. Note, 33 LEGAL BuLL. 324, 326 (1967). On the other hand, it is possible that the personnel of some smaller savings associations are not yet as well-trained in construction practices as the appraisers and inspectors of the larger associations.

While the discussion here is limited to savings and loan associations, the appraisal and inspection methods utilized by commercial and mortgage banks and other institutional lenders which make residential construction loans are apparently similar.

44 Bell Savings and Loan Association of Chicago, for instance, has a staff architect who reviews the plans and specifications of proposed developments. Bell Interview.

45 In California, for example, records of contractors' past performance are kept by the Building Material Dealers' Credit Association and by the California Savings and Loan League. Lefcoe \& Schaffer, Construction Lending and the Equitable Lien, 40 S. CaL. L. REv. 439, 448 n.23 (1967) [hereinafter cited as Lefcoe \& Schaffer].

46 In Chicago one agency normally supplies the relevant information on land developers. Credit reports average between three and ten pages. Many associations will not provide a construction loan for a developer unless he has borrowed from them before and has performed satisfactorily during earlier loan periods. First Federal Interview. 
specifications takes place at the loan application stage, but it is treated separately here because in appraisal the loan association is judging the contemplated project, and not the reliability of the builder himself.

The appraisal process includes a visit by loan association appraisers to the project site to survey the land, estimate the market value of the finished houses, and determine the accuracy of the proposed construction costs. If the building plans appear to be poorly adapted to the site, appraisers will recommend that the loan association reject the application or require the developer to alter his plans. ${ }^{47}$ The appraisers make a close inspection of soil conditions and other factors which are potential foundation hazards. ${ }^{48}$ Frequently the loan association will require geological surveys, soil percolation tests, and comprehensive testing by an engineering firm, usually at the borrower's expense. ${ }^{49}$

Appraisal also involves an examination of the plans and specifications themselves. Those savings and loan associations with a staff architect will review the builder's plans and specifications to make sure that minimum requirements are met and that the houses will be marketable. ${ }^{50}$ Other associations seek outside assistance. For instance, the Biscayne Federal Savings and Loan Association in Miami works with five local architects who serve as a rotating team of consultants. Each architect in turn attends a weekly meeting of the loan committee and evaluates designs submitted by applicant builders. The loan committee will reject applications on the basis of an architect's unfavorable report. ${ }^{51}$

3. Inspection of the Construction Site. Savings and loan officials have repeatedly emphasized that a vital function served by site inspection is to ensure that adequate and reasonable workmanship is being achieved by builder-borrowers. ${ }^{52}$ Trained inspectors with construction

47 United States Savings \& Loan League, Construction loan Procedures 5 (1966).

48 Id. at 36.

40 Id. Chicago loan officers who were interviewed all concurred that they would not consider seriously a loan application for development on potentially dangerous soil without a thorough percolation test report guaranteeing the quality of the soil. Most areas of northern Illinois, however, are "safe" for construction and frequently a soil test is not required.

50 Bell Interview.

51 Odell, Combatting Ugliness in America, in United States Savings \& Loan League, SAvings \& LoAN ANNAIS 1964 at 108, 110.

62 Of course, another major purpose of site inspections is to check on the progress of construction in order to disburse or withhold loan funds. The dual purposes of inspection are described in the Construction Lending Guide:

The underlying purposes of inspection are to verify that construction has reached a previously agreed-on stage, and that its quality meets the requirements of the loan commitment. The inspector should always make certain that the builder maintains a good quality of workmanship: After all, the association may one day 'own' the property and would like for it to be saleable.

CONSTRUGTION LOAN PrOcEDURES, supra note 47 , at 8. 
backgrounds are often sent by the savings associations to development sites either weekly or on a continuous basis ${ }^{53}$ to examine the construction in progress. The most serious structural defects usually occur in the house's foundation, ${ }^{64}$ and loan associations require inspectors to report such defects at the earliest possible time, since many items can be concealed upon completion of the house.55

If an inspector's report reveals a structural defect, loan associations frequently withhold loan funds until the defect has been corrected. A loan officer of the largest savings and loan association in Chicago explained that developers realize that they are under close scrutiny, and consequently demand high standards of subcontractors in order to receive progress payments promptly. ${ }^{56}$ Moreover, some loan associations withhold ten per cent of the loan fund in all cases until after the purchaser has moved into the completed house and has found it satisfactory. ${ }^{57}$

Thus, it appears that savings and loan associations have the expertise, the facilities, and the financial bargaining power to influence land developers to meet adequate standards of construction workmanship. The courts should consider this ability to control builders' conduct in determining whether savings and loan associations should be required to protect home purchasers from structural defects.

\section{The Desirability of Shifting Losses from Home Purchasers to CONSTRUCTION LENDERS}

Home purchasers seeking to hold lending institutions liable for damages caused by structural defects in housing will present the courts with cases of first impression. An analogous issue has frequently been litigated, however, in the context of credit sales of defective goods to unknowing consumers. ${ }^{58}$ A short discussion of these consumer sales

53 Id. at 37.

54 Bearman, supra note 3, at 545. Lester J. Ballerine of First Federal Savings of Chicago indicated that inspectors are instructed to be most careful in checking home foundations for cracks and reporting such structural defects. First Federal, on learning of such defects, will withhold loan proceeds until the developer has corrected them. First Federal Interview.

55 Construction LoAn Procedures, supra note 47, at 8. The inspection report used by inspectors of Talman Federal Savings and Loan Association of Chicago contains a checklist of 107 items, ranging from foundations and framing of steel beams and floors to such minor items as storm doors, interior painting, and ornamental iron.

56 First Federal Interview.

s7 First Federal Interview. This is apparently a widespread practice. See Construction LoAN Procedures, supra note 47, at 37.

58 See generally Gilmore, The Commercial Doctrine of Good Faith Purchase, 63 Yare L.J. 1057, 1093-1102 (1954); Note, Translating Sympathy for Deceived Consumers into 
cases may be useful in determining whether savings associations should be required to protect home purchasers from faulty construction by builder-vendors.

Frequently a buyer on credit makes a down payment and signs a negotiable promissory note for the balance secured by a conditional sales contract or chattel mortgage. ${ }^{59}$ The note usually provides for installment payments over an extended period of time. Often the dealer immediately assigns or sells the note at a discount to a finance company which has financed the dealer's inventory, prepared the consumer note, and made credit checks on both the dealer and buyer. ${ }^{60}$ If the credit merchandise proves defective or if the buyer never receives it, the financer frequently continues to demand the full contract price from the buyer under the buyer's obligation on the negotiable promissory note. ${ }^{61}$ In subsequent litigation on the note, if the consumer attempts to assert defenses of breach of warranty, failure of consideration, or fraud, the finance company typically will claim insulation as a "holder in due course" of the note. ${ }^{62}$ But several recent decisions have denied the financing institutions this insulation. ${ }^{63}$

The courts have given several reasons for protecting consumers in these situations. Many decisions rest upon the close relationship between the financer and the dealer. ${ }^{64}$ The courts frequently emphasize that the lending institution is familiar with all the details of the transaction involved, and that "in a very real sense, the finance company

Effective Programs for Protection, 114 U. PA. L. Rev. 395, 414-18 (1966); Note, Consumer Sales Financing: Placing the Risk for Defective Goods, 102 U. PA. I. REv. 782 (1954).

50 See, e.g., Mutual Fin. Co. v. Martin, 63 So. 2d 649 (Fla. 1953) (conditional sales contract); Swanson v. Commercial Acceptance Corp., 381 F.2d 296 (9th Cir. 1967) (chattel mortgage).

60 See Unico v. Owen, 50 N.J. 101, 232 A.2d 405 (1967).

61 In practice, however, the financing institution often "will respect a valid claim that the goods are defective and will attempt to secure an adjustment between the buyer and dealer before taking any action against the buyer." Note, supra note 58, 102 U. PA. L. REv. at 785.

62 See UnIForm COMmercial CODE $\S 3-305$. This problem will also arise under a similar set of facts in which there is no promissory note. The dealer often inserts a provision in the sales contract that the buyer promises he will not assert any contractual defenses against an assignee of the dealer. Under the Uniform Commercial Code, the assignee of such a contract is apparently accorded the same immunity from defenses as a holder in due course under § 3-305. See Uniform Commercial Code § 9-206.

63 See Palmer v. Associates Discount Corp., 124 F.2d 225 (D.C. Cir. 1941); Commercial Credit Corp. v. Orange County Mach. Works, 34 Cal. 2d 766, 214 P.2d 819 (1950); Mutual Fin. Co. v. Martin, 63 So. 2d 649 (Fla. 1953); Unico v. Owen, 50 N.J. 101, 232 A.2d 405 (1967); Westfield Inv. Co. v. Fellers, 74 N.J. Super. 575, 181 A.2d 809 (1962); Buffalo Indus. Bank v. De Marzio, 162 Misc. 742, 296 N.Y.S. 783 (City Ct. Buffalo 1937); Davis v. Commercial Credit Corp., 87 Ohio App. 311, 94 N.E.2d 710 (1950).

64 See, e.g., Commercial Credit Corp. v. Orange County Mach. Works, 34 Cal. 2d 766, 214 P.2d 819 (1950); Mutual Fin. Co. v. Martin, 63 So. 2d 649 (Fla. 1953). 
[is] a moving force in the transaction from its very inception, and act $[s]$ as a party to it." 65

The courts also rely on the argument that the financer is a "better preventer" of fraudulent sales. ${ }^{68}$ While the consumer normally buys on credit from the retail dealer only sporadically, does not have occasion to know of the dealer's financial position, and is unable to exercise any control over the dealer's business operation, the lending institution which finances the dealer's inventory and credit sales often has both the facilities and the bargaining power to "oversee the dealer's business" and prevent credit sales of defective merchandise by insolvent or undercapitalized dealers. ${ }^{67}$

A third policy underlying recent consumer sales cases which allow buyers to assert defenses against assignees is the belief that institutional lenders are better able to bear the initial impact of the financial loss caused by the dealer's insolvency than is the low-income consumer. ${ }^{68}$

There are several differences, however, between the sales and real property situations. In the consumer sales cases the moving party in litigation is normally the financer, and the consumer asserts his claims against the dealer as a defense to the action on the note. In the home purchase situation, on the other hand, presumably the aggrieved purchaser will initiate litigation directly against the financer when his products liability remedies prove inadequate because of the builder's insolvency. This may be more than merely a procedural difference. Although consumer credit decisions have allowed the buyer to assert contractual defenses, no court has held that the financing institution has an affirmative $d u t y$ to police the retail dealer for the protection of the consumer. To the extent that home purchasers ask the courts to impose such a duty upon construction lenders, they will be going beyond the scope of protection afforded by the contractual defenses in the consumer credit cases, and instead extending the scope of products liability.

Another difference between the consumer credit sales and home purchase situations is that in a sale of goods on credit the consumer originally contracts to pay the dealer for the goods, and the dealer

65 Commercial Credit Corp. v. Orange County Mach. Works, 34 Cal. 2d 766, 771, 214 P.2d 819, 822 (1950). See Palmer v. Associates Discount Corp., 124 F.2d 225 (D.C. Cir. 1941).

66 "The financing institution holds a dominant position in three-party installment sales and is better equipped than the average buyer to check on the over-all operations and continuing solvency of its dealers." Note, supra note 58, 102 U. PA. L. REv. at 793.

67 For an opinion which discusses at great length a finance company's ability to exercise control over the dealer's business operations, see Unico v. Owen, 50 -N.J. 101, 232 A.2d 405 (1967).

68 See Mutual Fin. Co. v, Martin, 63 So. 2d 649, 653 (Fla. 1953). 
then assigns the consumer's note to the finance company, ${ }^{69}$ while in the home purchase situation the purchaser deals independently with the lending institution at the same time that he negotiates to purchase his home from the builder-vendor. ${ }^{70}$ If one lending institution finances the builder's development costs and another institution becomes the purchaser's mortgagee, the sales analogy breaks down. In such a case there is no apparent reason why the purchaser should be allowed to avoid his own mortgage obligations, since the mortgagee was not the lender who chose the builder and appraised and inspected the building development. However, the construction lender actively seeks the mortgage loan, and in many instances the same institution finances both development and purchase. ${ }^{71}$ Thus, in the usual case, the analogy to consumer credit sales applies.

Should an aggrieved purchaser choose to seek relief from the construction lender in cases in which the construction lender is not also the mortgagee of the home purchase, there is no direct relationship between the lender and the purchaser, as there is in the sales cases. However, if a duty is to be imposed upon construction lenders in any case, it will probably not be predicated upon a direct relationship between the financer and the purchaser, but upon a close relationship between the lender and the builder-vendor. The issue whether a construction lender should have a duty to protect home purchasers from structural defects should not turn on the question whether the lender also provides the purchaser's mortgage funds. ${ }^{72}$

Some of the considerations underlying the consumer sales cases appear to be present in the home purchase situation. As in the consumer sales context, there exists a very close relationship between the construction lender and the land developer. Since the speculative land developer is often inefficient $t^{73}$ and financially irresponsible, ${ }^{74}$ the loan association is necessarily intertwined in the building process in order to

68 In the normal transaction both the conditional sales contract and the promissory note are prepared forms, printed by the finance company. The two instruments typically are attached but easily severable by a perforation so that the dealer can keep the contract and assign the negotiable note to the finance company. Frequently the consumer is not even aware that he is signing two separate instruments. $C f$., Commercial Credit Corp. v. Orange County Mach. Works, 34 Cal. 2d 766, 768, 214 P.2d 819, 820 (1950).

70 Thus, in some instances the lending institution which provides the purchaser's mortgage funds has no connection at all with the builder-vendor. But where the construction lender has a penalty agreement with the builder-vendor, the purchaser will frequently negotiate his mortgage with the same institution which finances the development. See note 37 supra and accompanying text.

71 See note 37 supra and accompanying text.

72 See text accompanying notes $97-105$ infra.

73 See Brehm at 113, 118, 124; Lefcoe \&: Dobson at 1271, 1293.

74 See notes 12 and 26 supra and accompanying text. 
protect its investment. It is submitted that because savings and loan participation in residential construction is so extensive, ${ }^{75}$ construction lenders are often more closely related to their borrowers than are the lending institutions that finance the inventory and credit sales of dealers.

Applying the "better preventer" policy which underlies many of the consumer sales cases to the home purchase situation, it appears that the loan association is more capable than the purchaser of avoiding losses caused by faulty construction work by the builder-vendor. The typical purchaser is not skilled enough to inspect his home for structural defects before the sale, and the cost of hiring an architect "particularly [for] the average home buyer who has very likely mortgaged heavily in order to purchase even a modest unit in a typical housing development" is prohibitive. ${ }^{76}$ The most serious construction defects usually occur in the home's foundation; they can often be discovered only during the early stages of construction, and even those purchasers who are able to employ architects to inspect the builder's product may be unable to detect them if negotiations begin after construction is well along or is completed, as is frequently the case. ${ }^{77}$ Moreover, the average home purchaser is unlikely to have or be able to obtain specific information concerning the financial condition, experience, and reliability of the land developer. The construction lender not only has access to such information, ${ }^{78}$ but also is present to inspect each stage of construction. ${ }^{79}$

Recent decisions have recognized the superior ability of the savings and loan association to prevent unauthorized practices of construction borrowers. In suits by suppliers of labor and materials against loan associations for undisbursed construction loan funds when insolvent builder-vendors have failed to pay the suppliers, the courts are usually favorably disposed toward the materialmen.80 Two recent California appellate court decisions have ruled that the unpaid supplier is entitled to an equitable lien upon undisbursed loan funds. ${ }^{81}$ In essence, these

75 See notes 34-57 supra and accompanying text.

76 Bearman, supra note 3 , at 545 .

77 Census data reveal that in the September to December period of $1964,22 \%$ of all new homes were sold before their foundations were dug, $31 \%$ were sold while construction was in progress, and 47\% were sold after completion. 1965 FACT Book at 41 . One commentator has reported that most architects are reluctant to perform post-construction inspections. Bearman, supra note 3, at 545 .

78 See notes 45 \& 46 supra and accompanying text.

79 See notes 47-57 supra and accompanying text.

80 See, e.g., Smith v. Anglo-California Trust Co., 205 Cal. 496, 271 P. 898 (1928); Comment, Mechanics' Liens and Surety Bonds in the Building Trades, 68 YALE L.J. 138 (1958).

81 McBain v. Santa Clara Sav. \& Loan Ass'n, 241 Cal. App. 2d 829, 51 Cal. Rptr. 78 
equitable lien decisions are acknowledging that the loan association owes a duty to suppliers of materials and labor to prevent the builder from misspending loan funds. Commentators on the California cases recently pointed out:

The doctrine of the two cases is founded, then, on two assumptions about construction lending: First, speculative construction should be policed; Second, construction lenders have reasonable means at hand to prevent the defalcations which sometimes result. ${ }^{82}$

If materialmen are able to recover from construction lenders under this rationale, there is all the more reason why home purchasers should be protected by lenders against structural defects. It has been suggested that the equitable lien cases are difficult for the courts because both the materialman and the lender have equal access to records which disclose developers' past performance. ${ }^{83}$ But home purchasers do not have access to these records, and normally have no available means of ascertaining the financial condition and past delinquency of the land developer who sells them their homes.

The "deeper pocket" theory sometimes used in the consumer credit decisions is at least equally applicable to home purchase situations. Buying a home is generally the largest investment a family ever makes. A latent structural defect leading to such serious damage as a cracked foundation could prove financially ruinous to a low or moderate income family unless the loss is shifted. In terms of ability to bear losses, therefore, it may be desirable to place the burden of an insolvent builder's faulty construction on the construction lender, especially if the lending institution is able to spread such losses over a significant portion of the housing market. ${ }^{84}$

This loss-spreading could be accomplished in two ways. First, the loan association could force builder-vendors to insure against "products liability" as a condition to receipt of a construction loan, thereby reducing or even eliminating the occasions where purchasers would seek redress from the association. Second, where builders do not insure or where insurance does not fully cover losses, loan associations might increase interest rates for construction loans to cover the contingency of their liability.

(Dist. Ct. App. 1966); Miller v. Mountain View Sav. \& Loan Ass'n, 238 Cal. App. 2d 644, 48 Cal. Rptr. 278 (Dist. Ct. App. 1965).

82 Lefcoe \& Schaffer at 446.

$83 \mathrm{Id}$. at 448 .

84 On risk-shifting and loss-spreading generally, see Calabresi, Some Thoughts on Risk Distribution and the Law of Torts, 70 Yale L.J. 499 (1961); James, An Evaluation of the Fault Concept, 32 Tenn. L. REv. 394 (1965); Blum \& Kalven, The Empty Cabinet of Dr. Calabresi: Auto Accidents and General Deterrence, 34 U. CH. L. REv. 239 (1967). 
Under either risk-spreading device, lenders will probably be able to shift losses to the builders of homes, primarily because of the inequality of bargaining power between the small land development corporation and the larger savings and loan association. The builder-vendor, in turn, may well be able to distribute at least part of the burden to home purchasers in general, in the form of higher housing prices. ${ }^{85}$ Such a loss-shifting process presumably will result in land developers and purchasers sharing the ultimate burden of loss caused by faulty construction.

The incidence of loss which builders may bear might lead to the departure of some marginal, undercapitalized developers from the residential construction industry. Developers with a history of delinquency will find it difficult to obtain construction loan funds because of the obligation imposed upon lending institutions to protect purchasers from further delinquency. Other builders with no history of delinquency who are undercapitalized may find it difficult to operate profitably because of increased construction costs. This will be especially true when housing demand is weak and added costs cannot easily be passed on in the form of higher prices.

Driving some undercapitalized land developers from the housing market would have mixed effects. Some commentators concerned with the quality of construction workmanship and with community aesthetics claim that the undercapitalized builder is more inefficient, careless, and apathetic toward organized community development than are his larger and more affluent competitors. ${ }^{86}$ On the other hand, an increase in construction costs forcing small, undercapitalized developers out of the residential construction industry would accelerate the recent trend toward fewer and larger land development firms. ${ }^{87}$ Such a result may restrict entry and decrease price competition in the industry.

Those increased construction costs which developers are able to pass on to home purchasers in the form of higher prices will spread the costs of compensating victims of construction defects among all purchasers. Higher prices might mean reduced housing demand, although several construction industry experts have argued that housing demand is relatively price inelastic and is affected more by change in family income levels and financing terms than by changes in the market price of housing. ${ }^{88}$ Passing the cost on would have its most significant impact

85 How much of the added construction costs builders will be able to pass on to purchasers depends upon several factors. See note 88 infra and accompanying text.

86 See Lefcoe \& Dobson at 1271; Brehm at 129-33 (discussing economies of scale).

87 See note 14 supra.

88 See Brehm at 122-23; Maisel, The Relationship of Residential Financing and Ex- 
in the lower and lower-middle income markets, where the risk of faulty construction, the cost of compensating for it, and price elasticity may be presumed to be greatest. This effect should not be exaggerated, however; passing the cost on to the consumer spreads it not only numerically but temporally, as well. Over the term of a mortgage, even relatively appreciable price increases will not significantly alter monthly payments.

\section{Theories and Scope of LIABILITY}

If lending institutions are to be held liable to purchasers for housing defects, the extent of that liability remains to be determined. The construction lender could be subject to liability for structural defects to the same extent that the financer of consumer goods is subject to contractual defenses. On the other hand, the courts may impose an affirmative duty upon the savings and loan association to protect home purchasers from structural hazards, following the lead of the California District Court of Appeal in Connor. As a third alternative, the construction lender might be considered the land developer's joint venturer in certain situations.

\section{A. A Solution Based on the Consumer Sales Analogy}

No decision has imposed an affirmative duty upon a finance company to police a dealer for the protection of consumers. The holdings of the sales cases have been limited to allowing defrauded consumers to interpose contractual defenses to complaints filed by credit financers. Because of the penalty provision inserted in many construction loan contracts, the construction lender frequently finances the purchases of homes in a housing development. ${ }^{89}$ The relationship between the construction lender as mortgagee and the home purchaser as mortgagor therefore resembles that between finance company and credit consumer. To carry the analogy to its logical conclusion, it can be argued that the loan association which finances housing developments should not be required to police construction to protect purchasers from products liability injuries, but should be subject to defenses which allege faulty construction in actions on the mortgage. The most usual context in which this argument would be applicable appears to be a

penditures on Residential Construction, in CONFERENCE ON SAVINGS AND RESIDENTIAL FINANCING, 1965 ProceEdings 130, 133.

While it is true that housing demand may have little price elasticity in the long run, it is likely that an immediate response of many low or lower-middle income purchasers to a rapid increase in the price of housing would be to "wait a year or two." There is no alternative that can be substituted for new housing except old housing or rental dwellings.

80 See note 37 supra and accompanying text. 
defense asserting a breach of the builder's implied warranty in an action for foreclosure.

The general rule in foreclosure cases is that the mortgagor may interpose to the mortgagee's complaint whatever defenses he believes he can establish. ${ }^{90}$ The validity of a mortgage may be impaired or destroyed by the absence or illegality of consideration for the promise of the mortgagor..$^{91}$ In allowing the mortgagor such defenses, the law of mortgages closely follows contract law, and the courts have frequently allowed purchasers to allege contractual defenses in foreclosure actions..$^{22}$ Mortgagors have also successfully interposed defenses of fraudulent misrepresentation regarding the mortgaged property and unconscionable conduct of the mortgagee..$^{93}$ It may be desirable to extend these defenses to the construction lender-mortgagee, just as the consumer sales cases have extended contractual and fraud defenses to financing institutions.

But this solution to the problem created by an insolvent buildervendor's poor workmanship is limited. First, it can be used only in cases in which the construction lender is also the mortgagee. The construction lender who does not finance a home purchase, however, may exercise at least as much control over the building process to protect its security. Second, personal injuries such as those suffered by the plaintiff in Schipper $v$. Levitt of Sons, Inc. ${ }^{94}$ in which an infant was severely burned as a result of the installation of faulty plumbing facilities, apparently will not be redressed fully when damages exceed the amount of the mortgage debt. ${ }^{95}$ Moreover, if the purchaser's injuries resulting from structural defects are limited to property damage, the anti-deficiency judgment statutes in many states already protect him against the mortgagee's claims to the extent of the difference between the depressed forclosure price and the fair market value of the house. ${ }^{96}$

\section{B. A Negligence Solution}

Since the consumer sales solution may prove inadequate to recompense home purchasers to the full extent of their injury, especially in

803 Poweld, REAL PRoperty § 464 (1967 Cum. Supp.).

91 Id. \& 444.

92 See cases cited in $i d$. on want of consideration.

93 Arizona Coffee Shops, Inc. v. Phoenix Downtown Parking Ass'n, 95 Ariz. 98, 387 P.2d 801 (1963) (unconscionable conduct of mortgagee); Sult v. Bolenback, 84 Ariz. 351, 327 P.2d 1023 (1958) (fraudulent representations regarding the mortgaged property).

9444 N.J. 70, 207 A.2d 314 (1965).

95 Nor will a purchaser suffering property damage to his home to an extent greater than his mortgage indebtedness be able to recoup his damages fully under the consumer sales analogy. $C f$. Bethlahmy v. Bechtel, 415 P.2d 698 (Idaho 1966) (new home unfit for habitation).

96 See note 40 supra. 
cases in which the construction lender is not also the purchase money mortgagee, the courts may instead follow the approach adopted by the intermediate appellate court in Connor ${ }^{97}$ and require construction lenders to exercise care in policing the workmanship of their borrowers. This would not require the construction lender to be the purchase mortgagee in order to find liability and would resemble liability for fault in other situations in which the law recognizes a duty of reasonable care to act affirmatively in controlling the conduct of another to prevent injury to a third person. This duty has been described in general terms:

If the conduct of the actor has brought him into a human relationship with another, of such character that sound social policy requires either some affirmative action or some precaution on his part to avoid harm, the duty to act or take the precaution is imposed by law. ${ }^{98}$

It has been suggested that the imposition of such a duty in a particular case depends upon the closeness of the relationship between the parties $^{99}$ and upon the existence of a reasonable opportunity to control the harmful conduct. ${ }^{100}$

Under such an analysis, the elements of a close relationship and the justification of policy seem to be present when a savings and loan association provides substantially all of a builder's capital and then thoroughly polices the builder's work, and a purchaser with little ability to inspect his home for latent structural defects is injured because of faulty construction. However, the third element-the existence of a reasonable opportunity to control the conduct of the buildervendor-will probably depend on the facts of specific cases.

Requiring the lender to exercise due care implies that the defect complained of must be of such a nature that it could be brought to the attention of the lending institution in its site inspections, appraisal surveys, or engineering reports. Most gross structural defects should be discoverable by a reasonably efficient and thorough inspection. ${ }^{101}$ It is unlikely, on the other hand, that even a careful inspection by savings and loan representatives would bring to light such defects as the negli-

97 Connor v. Conejo Valley Dev't Co., 61 Cal. Rptr. 333, 343-44 (Dist. Ct. App. 1967). 98 Harper \& Kime, The Duty To Control the Conduct of Another, 43 YALE L.J. 886 (1934). See James, Scope of Duty in Negligence Cases, 47 Nw. U.L. REv. 778, 809-13 (1953). 99 Harper \& Kime, supra note 98, at 887 .

$100 \mathrm{Id}$. at 888.

101 One loan officer in Chicago stated that a site inspector will report "rough structural defects," and the savings association will withhold loan funds until they are corrected. First Federal Interview. Presumably a "rough" defect is something more than trivial, but how much more is not clear. 
gent installation of potentially dangerous electrical wiring which bears a stamp of certification by an electrical engineering firm.

Courts applying a negligence standard for construction lenders who supervise the developer's building process might well require a standard of care similar to that imposed on architects and engineers who contract with owners to design buildings and act as general supervisors of the contractor's work. ${ }^{102}$ An early decision described that duty:

In performing the work which he undertook, it was [an engineer's] duty to exercise such care, skill and diligence as men engaged in that profession ordinarily exercise under like circumstances. He was not an insurer that the contractors would perform their work properly in all respects; but it was his duty to exercise reasonable care to see that they did so. ${ }^{103}$

It is submitted that a similar standard, when applied to the loan association which finances, appraises, and inspects a housing development, would not excessively burden the association. The prudent construction lender protecting its own investment would meet such a standard in any case.

From the viewpoint of social policy, it is likely that the negligence approach is superior to the consumer sales analogy in redressing home purchasers for injuries caused by the faulty construction of insolvent or undercapitalized builders. The obvious drawback of the negligence solution, however, is the lack of legal precedent for imposing such a duty upon a lending institution. Yet a court will normally find a duty in tort when changing social conditions lead reasonable men to agree that a duty should exist. ${ }^{104} \mathrm{New}$ legal duties frequently evolve when courts weigh the interests and policies involved in the disputes before them. ${ }^{105}$

\section{A Joint Venture Solution}

As an alternative to the negligence approach, courts seeking to go beyond the limited consumer sales solution may adopt a theory of joint venture to redress harms caused by faulty construction of insolvent or undercapitalized builder-vendors. The essence of a joint ven-

102 For cases on an architect's liability for negligent inspection of construction, see Pastorelli v. Associated Engineers, Inc., 176 F. Supp. 159 (D.R.I. 1959); Ehart v. Hummonds, 232 Ark. 133, 334 S.W.2d 869 (1960); Miller v. DeWitt, 37 IIl. 2d 273, 226 N.E.2d 630 (1967).

103 Cowles v. City of Minneapolis, 128 Minn. 452, 453-54, 151 N.W. 184, 185 (1915) (emphasis added).

104 See Prosser, TORTS § 334 (3d ed. 1964).

105 See Hergenrether v. East, 61 Cal. 2d 440, 393 P.2d 164, 39 Cal. Rptr. 4 (1964); Biakanja v. Irving, 49 Cal. 2d 647, 320 P.2d 16 (1958). 
ture is an intent to associate for a single or ascertainable series of transactions for a limited period of time, ${ }^{106}$ just as the construction lender is associated with the land developer for the limited purpose of each gaining a return from the sale of new houses.

What constitutes a joint venture is a matter of law, but whether a joint venture exists in a given situation is normally a question of fact. ${ }^{107}$ The elements usually said to be required for a relationship to constitute a joint venture are: an agreement, a joint interest, a sharing of profit and losses, control, a fiduciary relationship, and sometimes a right to an accounting. ${ }^{108}$ These elements are not rigid, and often courts will find the existence of a joint venture to do justice ${ }^{109}$ in a wide range of factual situations ${ }^{110}$ by stating that the real character, rather than the form, of a transaction should govern the relationship between the parties. ${ }^{111}$

The situation in which a lender provides substantially all of a builder-vendor's working capital, retains control over the building process, and is "motivated by prospective profits since it exacted for its loan not only maximum fees and charges, but a right of first refusal"112 on mortgages for all the homes sold, closely resembles a joint venture relationship between the builder-vendor and the construction lender. The California District Court of Appeal which held that a savings association could be liable to home purchasers under a negligence theory ${ }^{113}$ rejected joint venture in the Connor case, ${ }^{114}$ but the facts of that case are illustrative of the closeness of a construction loan situation to a relationship of joint venture.

In Connor, a "typical example of contemporary tract development,"115 the Great Western Savings and Loan Association loaned approximately three million dollars to an inexperienced developer (a former haberdasher) whose assets were only $\$ 5,000$ at the time of the loan agreement..110 The development in question involved the con-

108 Taubman, What Constitutes a Joint Venture, 41 CoRneld L.Q. 640, 650 (1956) [hereinafter cited as Taubman].

107 Id. at 640 n.1.

$108 I d$. at 643 .

$109 \mathrm{Id}$. at 652 .

$110 \mathrm{Id}$. at 650 .

111 Rubinstein v. Small, 75 N.Y.S.2d 483 (App. Div. 1947).

112 Connor v. Conejo Valley Dev't Co., 61 Cal. Rptr. 333, 340 (Dist. Ct. App. 1967).

113 See notes 18 \& 97 supra and accompanying text.

114 Connor v. Conejo Valley Dev't Co., 61 Cal. Rptr. 333, 342-343 (Dist. Ct. App. 1967).

Connor is now before the California Supreme Court. See note 17 supra.

11561 Cal. Rptr. at 336.

116 There is much dispute in the record concerning the developer's capitalization. The Conejo Valley Development Company was formed in March 1959 with a total capitalization of $\$ 5,000$ to develop the tract involved in the case. 61 Cal. Rptr. at 398 . A certified 
struction of 300 homes on a 100 acre subdivision which was to be the first stage of a 547 acre development to be financed by Great Western. The loan association advanced $\$ 150,000$ to purchase the tract, and later sold it in parcels to the builder as he received down payments for the sale of homes. Great Western expected a return of $\$ 600$ per house in the form of loan fees and charges ${ }^{117}$ and further profit from first trust deeds on the homes, which it was assured of obtaining because of a penalty provision in its construction loan agreement. ${ }^{118}$ The lender made extensive investigations of water conditions in the area but apparently overlooked a dangerous soil condition which eventually caused the foundations of many of the homes to buckle.

On this set of facts a court could easily find that the elements of joint venture are present, and submit the question of whether there actually was a joint venture to the jury. The parties agreed to jointly purchase the raw land with expectations of profits for both the developer and the savings association. That Great Western was to receive a fixed rate of return for its construction loan should not obscure the reality that whether Great Western earned a profit or suffered a loss directly depended on the success of the development.119 The control element is easy to find in such agreements. ${ }^{120}$ Moreover, a lender such as Great Western is entitled to a frequent "accounting" of the developer's profits and losses, especially because of the mechanic's lien cases and the use of progress payments. ${ }^{121}$

The advantage of the joint venture solution to the residential construction defects problem is that it enables the courts to rule as a matter of law whether or not the elements of joint venture are present in order to reach equitable results in each case. A potential danger of this approach is that savings associations could be held liable for defects over which they have no control. It is likely that the strict liability doctrine of Schipper $v$. Levitt \& Sons, Inc. ${ }^{122}$ will expand to more

public accountant interpreted a financial statement of July 31, 1959 to mean that the developer's net worth was slightly under $\$ 36,000$. Id. Although the developer may have paid $\$ 190,000$ into escrow for the purchase of the land, the appellate court surmised that this "investment" in fact represented advances against future loan withdrawals and sales income. $I d$.

117 The developer estimated that this figure represented $1 / 3$ of the gross profit on each house. $61 \mathrm{Cal}$. Rptr. at 337 .

118 On penalty agreements, see note 37 supra and accompanying text.

119 Courts frequently find joint ventures in situations in which there is no apparent profit sharing. See Planetary Recreations, Inc. v. Kerns, Inc., 54 N.Y.S.2d 418 (N.Y. Gity Ct. 1945). The distinction between a "loan" and a "joint venture" often is obscured in the decisions. Taubman at 651 .

120 See notes 35-57 supra and accompanying text.

121 See notes 80-83 supra and accompanying text.

12244 N.J. 70, 207 A.2d 314 (1965). 
jurisdictions. If Schipper is held to apply for minor defects which cannot be discovered even by a thorough inspection process, loan associations could be held liable without fault. However, since it is likely that construction lenders will require builder-vendors to insure against products liability as a condition to the construction loan agreement, and since a "secondary" tort feasor can often obtain indemnification from the actively negligent party in similar situations, ${ }^{123}$ this problem is not serious.

If a construction lender obtains mortgage rights on the home purchases, the argument for a joint venture relationship is strengthened. This is particularly true because the builder-vendor who induces purchasers to mortgage with the construction lender acts as the lender's agent, at least for this limited purpose. Joint venture depends upon a consideration of the totality of the facts, however, and the existence of a penalty clause in the construction loan agreement may not be essential to a finding of liability under this theory.

\section{Conclusion}

Under any of the three theories proposed here, the law would predicate lender liability for construction defects on the inspection practices which savings and loan associations have voluntarily adopted to protect their own interests in home building. Loan associations are likely to react by requiring builders to insure against liability for structural defects. Legislation requiring such insurance could of course provide the same protection for future purchasers. A court holding, however, would presumably be applicable to the rights and liabilities of parties affected by existing structural defects. This difference would have a significant effect upon the ability of construction lenders to shift initial losses.

123 See Miller v. DeWitt, 37 IIl. 2d 273, 226 N.E.2d 630 (1967) (architect can seek indemnification from negligent contractor). 